\title{
FOXN3 wt Allele
}

National Cancer Institute

\section{Source}

National Cancer Institute. FOXN3 wt Allele. NCI Thesaurus. Code C52528.

Human FOXN3 wild-type allele is located in the vicinity of $14 \mathrm{q} 31.3$ and is approximately $261 \mathrm{~kb}$ in length. This allele, which encodes forkhead box protein N3, is involved in the mediation of mitotic checkpoints. 